\title{
IDENTIFIKASI CEKUNGAN HIDROKARBON "RAE" BERDASARKAN DATA MAGNETOTELURIK DI DAERAH BULA, MALUKU
}

\author{
Gita Purna Rae Wanudya* ${ }^{* 1}$, Syamsurijal Rasimeng ${ }^{1}$, Rustadi ${ }^{1}$, Noor Muhammad Indragiri ${ }^{2}$ \\ ${ }^{1}$ Teknik Geofisika, Universitas Lampung \\ Jl. Prof. Dr. SumantriBrojonegoro No.1 BandarLampung 35145 \\ ${ }^{2}$ Pusat Survei Geologi \\ Jurusan Teknik Geofisika, FT UNILA \\ e-mail:*1 gitarae41@gmail.com
}

\begin{abstract}
ABSTRAK
Telah dilakukan penelitian menggunakan metode Magnetotelurik untuk mendapatkan model 2D berdasarkan variasi resistivitas batuan bawah permukaan. Tujuan penelitian ini adalah untuk menentukan zona formasi hidrokarbon. Metode penelitian yang dilakukan untuk mencapai tujuan penelitian antara lain, pertama dilakukan filtering pada data dengan proses robust. proses robust ini terdiri dari Robust No Weight, Robust Rho Variance dan Robust Ordinary Cohenerency. Kedua dilakukan seleksi XPR dan mengubah format Edi. Ketiga dilakukan inversi untuk mendapatkan model penampang 2D resistivitas. Berdasarkan hasil pengolahan data dari delapan titik pengukuran metode Magnetotelurik diperoleh informasi formasi batuan. Formasi hidrokrabon yang terdapat pada daerah penelitian ini adalah reservoar dan caprock. Kedalaman sampai dengan $1600 \mathrm{~m}-2700 \mathrm{~m}$ di bawah permukaan dengan nilai resistivitas $12 \mathrm{~m}-33 \mathrm{~m}$ diduga terdapat batu lempung (clays) yang diindikasikan sebagai caprock. Kedalaman $2700 \mathrm{~m}$ sampai dengan $5000 \mathrm{~m}$ dibawah permukaan dengan nilai resistivitas $41 \mathrm{~m}-250 \mathrm{~m}$ diduga batu pasir terisi minyak (oil sands) yang diindikasikan sebagai reservoar. Untuk jebakan atau trap pada formasi hidrokarbon ini termasuk pada jebakan struktural, yaitu terdapat jebakan antiklin.
\end{abstract}

\begin{abstract}
The research had been performed using Magnetotelluric to get a 2D model based on variations in resistivity of the subsurface rock. The purpose of this study was to determine the hydrocarbon formation zone. The research method to achieve the research objectives, among others, the first filtering performed on the data with a robust process. This process consists of Robust No Weight, Robust Rho Variance and Ordinary Cohenerency. The second step is done to change the format Selection XPR And Edi. A third inversion resistivity model for the review get a $2 \mathrm{D}$ cross section. Based on the findings of the eight data processing methods of measurement points obtained information Magnetotelluric rock formations. Formation hidrokrabon What are the areas is research a reservoir and caprock. The layer in $1600 \mathrm{~m}-2700 \mathrm{~m}$ depth from the surface which resisvity $12-33 \mathrm{~m}$ assumpted as clay cap. While the layer in $2700 \mathrm{~m}-5000 \mathrm{~m}$ depth from the surface with high resistivity 41- $250 \mathrm{~m}$ is assumpted as oil sands (reservoir). The trap zone of this hidrocarbon formation categorized into structural trap which is the trap of anticline.
\end{abstract}

Keywords - Hidrocarbon, Magnetotelluric, 2D model, Reservoar, Caprock 


\section{PENDAHULUAN}

Semakin berkembangnya peradaban, kesejahteraan dan jumlah populasi manusia berdampak pada meningkatnya kebutuhan sumber energi. Hingga saat ini sumber energi sebagian besar bergantung pada energi fosil berupa minyak bumi.

Dalam sistem pembentukan akumulasi minyak dan gas bumi) menurut (Magoon dan Dow, 1994) terdiri dari beberapa unsur yaitu batuan induk (source rock), batuan reservoir, lapisan penutup (seal), perangkap (trap) dan proses migrasi (perpindahan) akumulasi minyak bumi.

Survei geofisika terutama dimaksudkan untuk memperoleh informasi mengenai distribusi parameter-parameter fisik di bawah permukaan. Metode magnetotellurik (MT) adalah suatu metode dari geofisika yang bersifat pasif yang memanfaatkan medan elektromagnetik alami sebagai sumber gelombang untuk mengetahui struktur tahanan jenis bawah permukaan.

Sifat fisik batuan yang dapat terukur adalah konduktivitas atau resistivitas batuan. Secara umum batuan dengan porositas tinggi yang berisi gas dan minyak biasanya dicirikan oleh nilai resistivitas yang relatif lebih tinggi.

\section{TINJAUAN PUSTAKA}

\subsection{Lokasi Daerah Penelitian}

Lokasi penelitian ini terletak di wilayah Bula di Kabupaten Maluku Tengah, Secara koordinat berada pada 4 00' LS. Batas utara dan timur ialah Laut Seram, di selatan Laut Banda dan di barat Lembar Masohi.

\subsection{Geologi Regional}

Pada tahun 1975 Paten dan Zillman menyelidiki geologi daerah Bula dalam rangka pencarian minyak dan gasbumi. Beberapa ahli geologi dari Inggris pada tahun 1976 juga melakukan penyelidikan di beberapa tempat di Pulau Seram.

\subsection{Stratigrafi}

Batuan yang tersingkap di Lembar Bula adalah batuan malihan yang terdiri dari sekis Kompleks Kabipolo (Pzta), batuan tersebut diduga berumur Perem dan tertindih tak selaras oleh batuan yang berumur Trias sampai Jura.

Di beberpa tempat sentuhannya berupa sesar. Batuan Trias-Juara terdiri dari Formasi Kanikeh ( $\mathrm{JK}$ ) berupa sediemn tipe "flysch" atau turbidit dan Formasi Manusela ( JM) berupa batugamping.

Formasi Kanikeh terdiri dari perulangan batupasir, batulanau dan

batulempung. Hubungannya dengan Formasi Manusela menjemari.

Formasi Sawai (Ks) terdendapkan pada Zaman Kapur, formasi ini menindih takelaras Formasi Kenikeh dan Formasi Manusela. Formasi Sawai terdiri dari kalsiluit yang di beberapa tempat bersisipan serpih merah dan rijang dengan radiolaria.

Formasi ini menindih selaras Formasi Sawai, umurnya Paleosen-Eosen. Formasi Selagor (Toms) berumur Oligosen Akhir sampai Miosen Awal yang terendapkan dan menindih selaras Formasi Hatuolo.

Kala Pliosen terendapkan Formasi Wahai (Tpw) terdiri dari napal bersisipan batugamping pasiran dan batupasir halus. Hubungan Formasi ini dengan Kompleks tidak jelas dan di beberapa tempat berupa sesar. Diatas formasi Wahai, didapati Formasi Wahai didapati, Formasi Fufa (Qpf) yang berumur Plistosen dan terdiri dari batupasir halus-kasar, batulanau, batulempung, lensa konglomerat dan gambut. 
Dibeberapa tempai
batugamping Formasi Fufa (Qpfl).

Hubungan formasi tersebut dengan

Formasi Wahai adalah selaras. Formasi

Fufa tertindih selaras oleh terumbu koral terangkat $(\mathrm{Ql})$ dan aluvium (Qa) (Audley dan Charles, dkk., 1975).

Formasi dalam Pulau Seram, adalah sebagai berikut:

\section{a. Qa (Aluvium):}

Lanau, pasir dan kerikil, terdapat di sepanjang daerah S. Bobot dan S. Masiwang serta di daerah pantai utara dan selatan disekitar muara sungai.

\section{b. Qpf (Formasi Fufa):}

Batupasir halus, batulanau, batulempung dan lensa konglomerat serta gambut. Batuannya berwarna kelabu muda dan berlapis tipis. Komponen batuan terdiri kuarsa, rijang, batupasir, batulanau dan batulempung yang berwarna kehijauan dengan massadasar pasir yang mengandung mika.

Tebal lensa tersebut sampai $20 \mathrm{~cm}$. Satuan ini tersingkap di sekitar W. Masiwang dan W. Semos, di bagian timur Lembar dan sekitar Fufa, tebalnya melebihi 300m. (Zillman dan Paten, 1975).

\section{c. Qpfl (Formasi Fufa):}

Anggota batu gamping atau gamping berwarna putih, padat, berlapis, mengandung banyak kepingan koral dan ganggang. Bagian bawah terdiri dari konglomerat, terdiri dari batupasir yang padat, batulanau,batulempung, rijang dan batuan malihan.

Batugamping foraminifera mengandung hampir $90 \%$ plangton dan pengawetan cangkang yang cukup baik. Batu gamping ini pada umumnya menunjukkan hubungan menjemari dengan Formasi Fufa (Qpf).

\section{d. Q1:}

Terumbu koral terangkat: batugamping koral, berongga dan berstruktur terumbu. Satuan ini terdapat di sekitar P. Parang, P. Akat, P. Seram Rai, P. Seram Laut, Kep. Gorong dan Kep. Watubela.

\section{e. Pzta}

Kompleks Kabipoto: sekis mika, sekis tremolit aktinolit, sekis klorit, batupualam, terdaunkan, sekis epidot, sekis amfibol dan genes.

\section{f. Batuan Ultramafik:}

Serpentinit, piroksenit dan dunit, berwarna kelabu tua, kehijauan sampai kehitaman. Batuan ini tersingkap di sebelah tenggara dan selatan P. Seram, P. Tibor, P. Watubela dan P. Gorong.

\section{g. Tmps:}

Kompleks Salas: bongkahan atau kepingan yang berasal dari batuan sedimen, batuan beku dan batuan malihan yang tidak diketahui sumbernya. Berukuran melebihi 10m dan mempunyai umur yang berbeda-beda.

\section{h. Tpw:}

Formasi Wahai: napal berwarna putih kekuningan sampai kelabu muda, lunak dan berlapis tipis sampai setebal dari $1 \mathrm{~m}$.

\section{i. KTn:}

Kompleks NIF; Kalsilutit, serpih dan napal yang tidak dapat dipisahkan, litologinya dapat dibandingkan dengan Formasi Sawai, Formasi Hatuolo dan 
Formasi Selagor. Satuan ini telah terlipat kuat sehingga banyak terjadi perulangan dalam jarak dekat.

\section{i. Toms:}

Formasi Selagor: batugamping di beberapa tempat kalsilutit, napal dan bersisipan serpih, berwarna putih, kelabu dan coklat, agak kompak. Pada dasarnya kalsilutit ini tidak berlapis, sebagian tersilikakan dan terbreksikan.

\section{k. Teh:}

Formasi Hatuolo: serpih pasiran berwarna merah bata-kecoklatan, berlapis baik.

\section{l. Ks:}

Formasi Sawai: kalsilutit, berwarna putih sampai kekuningan.

\section{m. JM:}

Formasi Manusela: batugamping berwarna putih kotor sampai kelabu, berlapis baik di bagian bawah dan makin ke atas perlapisannya makin kabur.

\section{n. JK:}

Formasi Kanikeh: perulangan antara batupasir, bataulanau dan batulempung yang merupakan sedimen tipe "flysch".

\subsection{Struktur dan Tektonika}

Sebagian besar batuan di Lembar Bula, yang umurnya berkisar Pra-Tersier sampai Miosen terlah terlipat kuat dan tercenangga Bagian ini meliputi batuan malihan, Formasi Kanikeh, Formasi
Manusela, Formasi Sawai, Formasi Hatuolo, Formasi Selagor dan Kompleks Nif.

Arah sumbu lipatan dari barat-timur sampai baratlaut-tenggara, pada umumnya besar sudut kemiringannya melebihi 30 . Batuan yang lebih muda seperti Formasi Fufa dan Formasi Wahai, terlipat lebih lemah dengan sumbu lipatan secara umum hampir sejajar dengan arah memanjang.

\section{TEORI DASAR}

\subsection{Teori Cekungan Hidrokarbon}

Cekungan sedimen merupakan akumulasi sedimen yang memegang peranan penting bagi akumulasi minyak dan gas bumi. Di dunia ini terdapat lebih dari 600 cekungan sedimen, dan sekitar seperempatnya telah menghasilkan minyak.

Kehadiran minyak bumi tergantung pada cekungan dan sangat bergantung pada batuan sumber, perkembangan reservoir, jalan migrasi, pembentukan perangkap, dan keberadaan batuan penutup yang baik (Moehadi, 2011).

Analisa Cekungan Sedimen adalah suatu daerah rendahan yang terjadi akibat proses tektonik, dimana sedimen terendapkan. Dengan demikian cekungan sedimen merupakan depresi sehingga sedimen terjebak di dalamnya (Boggs, 2001).

\subsection{Prinsip Dasar Metode MT}

Metode magnetotelurik merupakan salah satu metode geofisika yang memanfaatkan variasi medan elektromagnetik yang terdapat pada permukaan bumi.

Variasi medan tersebut berasal dari batuan-batuan di bawah permukaan bumi yang terinduksi oleh medan elektromagnetik yang terdapat pada 
atmosfer bumi. Variasi medan elektromagnetik yang terukur nantinya diterjemahkan menjadi nilai resistivitas yang kemudian dimodelkan baik secara vertikal maupun lateral (Vozoff, 1991).

Variasi pada medan magnet bumi alami tersebut menghasilkan interval frekuensi dari $0,001 \mathrm{~Hz}$ sampai dengan $10 \mathrm{~Hz}$. Gambar 1. merupakan penjalaran gelombang elektromagnetik.

Dalam tesisnya Xiao (2004) mengatakan bahwa ada dua sumber utama sinyal elektromagntik alamiah yang digunakan dalam metode magnteotelurik, yaitu:

1. Sinyal yang berfrekuensi antara 1-10 $\mathrm{kHz}$, medan elektromagnetik alamiah ini dihasilkan dari atmosfer bumi akibat aktivitas cuaca ataupun kilat (lightning), dapat dilihat pada.

2. Sinyal berfrekuensi di bawah $1 \mathrm{~Hz}$, berasal dari fluktuasi medan magnet bumi yang disebabkan oleh perubahan dalam magnetosphere. Magnetosphere adalah zona kompleks plasma yang secara konstan terdorong oleh solar wind menunjukkan medan elektromagnetik oleh solar wind.

\subsection{Persamaan Pada Metode MT}

\subsubsection{Persamaan Maxwell}

Persamaan Maxwell merupakan sintesa hasil-hasil eksperimen (empiris) mengenai fenomena listrik-magnet yang didapatkan oleh Faraday, Ampere, Gauss, Coulomb disamping yang dilakukan oleh Maxwell

sendiri. Dalam bentuk diferensial, persamaan Maxwell dalam domain frekuensi dapat dituliskan sebagai berikut:

$$
\begin{aligned}
& \nabla x \boldsymbol{E}=-\frac{\partial B}{\partial t} \\
& \nabla \boldsymbol{x} \boldsymbol{H}=\boldsymbol{j}+\frac{\partial D}{\partial t} \\
& \nabla . \boldsymbol{D}=\boldsymbol{q} \\
& \nabla . \boldsymbol{B}=\boldsymbol{0}
\end{aligned}
$$

Persamaan (1) menunjukkan hukum Faraday, dimana medan listrik dihasilkan dari medan magnet yang berubah terhadap waktu. Persamaan (2) merupakan generalisasi teorema Ampere dengan memperhitungkan hukum kekekalan muatan.

Persamaan tersebut menyatakan bahwa medan magnet timbul akibat fluks total arus listrik yang disebabkan oleh arus konduksi dan arus perpindahan. Persamaan (3) menyatakan hukum Gauss yaitu fluks elektrik pada suatu ruang sebanding dengan muatan total yang ada dalam ruang tersebut.

Sedangkan persamaan (4) yang identik dengan persamaan (3) berlaku untuk medan magnet, namun dalam hal ini tidak ada monopol magnetik.

Hubungan antara intensitas medan dengan fluks yang terjadi pada medium homogen dinyatakan oleh persamaan berikut;

$$
\begin{aligned}
& B=\mu H \\
& D=\varepsilon E \\
& J=\sigma E=\frac{E}{\rho}
\end{aligned}
$$

Dengan demikian akumulasi muatan seperti dinyatakan pada persamaan (3) tidak terjadi dan persamaan Maxwell dapat dituliskan kembali sebagai berikut:

$$
\begin{aligned}
& \nabla x \boldsymbol{E}=-\mu \frac{\partial H}{\partial t} \\
& \nabla x \boldsymbol{H}=\sigma E+\varepsilon \frac{\partial E}{\partial t} \\
& \nabla . \boldsymbol{E}=\mathbf{0} \\
& \nabla . H=0
\end{aligned}
$$

\subsubsection{Skin Depth}

Skin Depth didefinisikan sebagai kedalaman dimana amplitudo gelombang berkurang hingga lebih menjadi sepertiga amplitudo awal. Dalam medium 1D yang homogen diperoleh; 


$$
\begin{aligned}
& \delta=0.5 \sqrt{\rho T} \\
& \delta=503 \sqrt{\frac{\rho}{f}}(\mathbf{k m})
\end{aligned}
$$

\subsubsection{Model Bumi 2-D}

Dalam kasus bumi tidak homogen (2-Dimensi) dikenal dengan adanya modus TE (Transverse Electric) dan TM (Tranverse Magnetik). Pada kasus 2 dimensi, nilai resistivitas tidak hanya bervariasi secara vertikal tetapi juga horisontal. Polarisasi tersebut berhubungan dengan arah strike kondisi lapangan p.engukuran.

Dikatakan modus TE adalah medan listrik sejajar dengan strike dan medan magnet tegak lurus dengan strike. Jika strike diasumsikan arah $\mathrm{x}$, maka $\mathrm{E}$ berada pada arah x dan B pada y dan $\mathrm{z}$.

$$
\begin{aligned}
& \frac{\partial B z}{\partial y}-\frac{\partial B y}{\partial z}=\mu \sigma E x ; \frac{\partial E x}{\partial z}=-\hat{i} \omega B y ;-\frac{\partial E x}{\partial y}=- \\
& i \omega B z
\end{aligned}
$$

Modus TM adalah medan magnet sejajar dengan strike dan medan listrik tegak lurus dengan strike. Sehingga modus TM lebih efektif dalam melokalisir perlapisan antara daerah yang berbeda resistivitasnya (Xiao, 2004).

$$
\begin{aligned}
& \frac{\partial E z}{\partial y}-\frac{\partial E y}{\partial z}=-i \omega B x ; \frac{\partial B x}{\partial z}=\mu \sigma E y ;-\frac{\partial B x}{\partial y}= \\
& \mu \sigma E z
\end{aligned}
$$

\subsection{Pengolahan Data MT}

\section{Time Series}

Langkah awal yang dilakukan dalam pengolahan data tersebut adalah mengubah domain data time series dari domain waktu menjadi domain frekuensi. Hal tersebut dilakukan dengan menggunakan transformasi fourier.

\section{Transformasi Fourier}

Secara prinsip, transformasi fourier adalah suatu operasi matematis yang merubah sinyal menjadi spektrum. Proses tranformasi ke dalam domain frekuensi ini dilakukan karena parameter fisis seperti impedensi, resistivitas semu, dan fase merupakan fungsi frekuensi.

Dalam data MT, transformasi fourier biasanya digunakan untuk mengubah time series komponen terukur (hx, Hy, Hz, Ex dan Ey) ke dalam domain frekuensi (Simpson dan Bahr, 2005).

Pada penelitian ini menggunakan Fast Fourier Transform (FFT) merupakan teknik komputasi yang mampu untuk menangani transformasi fourier dari data diskrit dengan jumlah yang banyak secara efisien.

Proses penghilangan noise ini dilakukan dengan teknik robust. Teknik ini dilakukan dengan mengeleminasi pengaruh dari titik data (disebut dengan outlier) yang tidak mempresentasikan keseluruhan data.

Kemudian setelah noise data dikurangi dengan teknik robust, kita dapat menghitung nilai impedensi, resistivitas semu dan fase.

Impedensi adalah perbandingan antara medan magnet dan medan listrik, hubungan linier antara medan magnet dan medan listrik dapat dirumuskan pada persamaan sebagai berikut (Smirnov, 2003).

\subsection{Sistem Hidrokarbon}

Suatu proses berkesinambungan bagaimana suatu hidrokarbon bisa terbentuk dan terakumulasi sehingga selanjutnya menjadi hidrokarbon yang bisa di produksi. Proses ini secara umum melalui beberapa tahapan - tahapan sebagai berikut (Koesoemadinata, 1980); 


\section{Source Rock (Batuan Induk)}

Batuan induk atau sering disebut juga dengan batuan sumber adalah dimana minyak dan gas bumi terbentuk.

\section{Reservoar}

Batuan yang mampu menyimpan dan mampu mengalirkan hidrokarbon dan permibilitas sebagai tempat megalirnya hidrokarbon, seperti batuan pasir atau karbonat. Batuan reservoar umumnya terdiri dari batuan sedimen, yang berupa batupasir dan karbonat (sedimen klastik) serta batuan shale (sedimen non-klastik) atau kadang-kadang vulkanik.

\section{Caprock (Batuan Penutup)}

Batuan penutup adalah batuan impermeable yang terletak diatas reservoar, sehingga hidrokarbon tidak akan keluar dari perangkap.

\section{Trap (Jebakan)}

Bentuk dari geometri atau facies yang mampu menahan minyak dan gas bumi untuk berkumpul dan tidak berpindah lagi. Suatu trap harus terdiri dari batuan reservoar sebagai tempat penyimpan hidrokarbon dan suatu set seal.

\section{METODE PENELITIAN}

\subsection{Alat dan Bahan Penelitian}

\section{Data Magnetotelurik;}

Data magnetotelurik yang digunakan adalah data sekunder di daerah hidrokarbon, Bula, Maluku Tengah. Data ini kemudian diolah menjadi model 2Dimensi untuk memperoleh persebaran nilai resistivitas bawah permukaan untuk mengidentifikasi formasi hidrokarbon.

\section{Software dan hardware}

Software yang digunakan dalam penelitian ini adalah Microsoft Office, Microsoft Excel, Software Surfer10, Software Global Mapper12, SSMT2000, MT Editor, dan WinGlink. Hardware yang digunakan yaitu, laptop Dell inspiron $\mathrm{n}$ series.

\subsection{Pengolahan Data}

1. Raw Data merupakan data mentah yang diperoleh pada saat pengukuran metode MT di lapangan dengan ekstensi .TBL.

2. Transformasi Fourier

Tahap berikutnya dalam pengolahan data untuk menghasilkan deret frekuensi dilakukan transformasi fourier (Fourier Transform) dari data waktu baku series. Adapun langkah-langkahnya meliputi:

a. Make PFT; Pada make PFT ini digunakan parameter yang sama untuk menghasilkan domain frekuensi.

b. TS to FT merupakan time series to fourier transform, dimana proses ini diterapkan koefisien Fourier data dari masing-masing parameter yang dipilih. Jendela akan menutup secara otomatis sekitar 10 detik setelah pengolahan berakhir.

c. Proccess; Menu proccess ini SSMT2000 akan membuka layar penuh jendela DOS dan memproses ulang transformasi Fourier.

\section{Robust Proccessing}

Robust proccessing adalah salah satu cara untuk menghilangkan noise, karena pada saat pengukuran yang terekam sinyal MT berupa data dan noise.

Dimana data merupakan informasi yang mengandung informasi keadaan geologi bawah permukaan di titik pengukuran, dan noise adalah data yang 
tidak mengandung informasi keadaan geologi bawah permukaan.

Prinsip robust proccessing adalah membagi data time series kedalam segmen - segmen dengan ukuran sama. Ada tiga macam robust proccessing yang diproses pada software SSMT2000, yaitu robust No Weight, robust Rho Variance dan robust Ordinary Coherency.

\section{Up Coherency}

Perhitungan nilai koherensi ini dilakukan di Microsoft Excel dengan menjumlahkan keseluruhan nilai TE dan nilai TM untuk dihitung berapa persen $(\%)$ nilai dari TE dan TM tersebut.

Pada perhitungan ini kita dapat melihat nilai koherensi tertinggi dan terendah dari masing-masing robust. Robust dengan koherensi tertinggi akan diproses lagi sesuai jenis robustnya, namun dengan melakukan upgrade koherensi pada edit parameter menjadi 0.95 dan 0.75 untuk reject crosspower. Untuk nilai koherensi $75 \%$ dapat dilanjutkan ke tahap seleksi cross power.

\section{Seleksi XPR}

Pada seleksi XPR ini dilakukan edit cross power dengan Software MTEditor, yang akan menampilkan kurva resistivitas semu dan fase, yaitu gelombang EM mode TE dan TM. Seleksi cross power merupakan tahapan terakhir sebelum melakukan inversi.

\section{Eksport Data (Edi file)}

Pada seleksi cross power file berupa ekstensi MTH dan MTL, untuk melakukan inversi, data harus diubah dalam bentuk file yang berekstensi MPK atau Edi file.

\section{Inversi}

Pengolahan inversi data MT menggunakan software WinGlink untuk menghasilkan model 2-Dimensi pada data sekunder MT yang terdiri dari delapan titik pengukuran di lintasan 2 .

\section{HASIL DAN PEMBAHASAN}

\subsection{Hasil Penelitian}

Pada data Bula terdapat satu line yang terdiri dari delapan titik pengukuran pengukuran. Durasi dalam pengukuran selama $12 \mathrm{jam}$. Lokasi pengukuran berada pada arah Barat Laut-Tenggara. Dari hasil pengolahan data dengan format (.EDI) yang telah dilakukan pengolahan awal dengan software MT Editor dengan melakukan seleksi XPR yang dapat dilihat pada Gambar 2.

Metode inversi menggunakan software WinGlink didapatkan model 2-D yang memetakan nilai resistivitas dan kedalaman.

Profile Line pada Maps adalah garis poligonal yang ditambahkan disepanjang delapan titik pengukuran.

\subsection{Model Sounding 1-D}

Untuk menentukan nilai resistivitas dan ketebalan lapisan dengan membuat model struktur 1D setiap titik pengukuran. Profil tahanan jenis 1-D dapat digunakan sebagai model awal proses pemodelan 2-D. Model sounding 1-D di titik pengukuran MT-BL08 ditunjukkan pada Gambar 3. Nilai resistivitas dan kedalaman dari setiap titik pengukuran dapat dilihat pada Tabel 1, Tabel. 2 dan Tabel. 3.Untuk titik pengukuran BL12 memiliki rentan $95.3 \mathrm{~m}$ - $5000 \mathrm{~m}$ dengan rentan nilai resistivitas antara 7,92 $\mathrm{m}-171,2 \mathrm{~m}$ diduga terdapat batu pasir berisi minyak (oil sands).

Titik pengukuran BL08 memiliki kedalaman $156.63 \mathrm{~m}$ - $5000 \mathrm{~m}$ dengan rentan nilai resistivitas dari 3,59-63,46 m terdapat batu lempung (clay).

Di titik pengukuran $1872 \mathrm{~m} 6$ memiliki rentan kedalaman 73,72 $\mathrm{m}$ $5000 \mathrm{~m}$ dengan rentan nilai resistivitas antara $8.3 \mathrm{~m}-74.99 \mathrm{~m} \mathrm{~m}$ diduga terdapat batuan lempung (clay). 
Titik pengukuran Salm5m1 memiliki rentan kedalaman $81,75 \mathrm{~m}-5000 \mathrm{~m}$ dengan rentan nilai resistivitas batuan antara 2,75 $\mathrm{m}-28,84 \mathrm{~m}$ diduga terdapat batu lempung (clay). Di titik pengukuran $1872 \mathrm{~m} 7 \mathrm{a}$ memiliki rentan kedalaman $115.58 \mathrm{~m}-5000 \mathrm{~m}$ dengan nilai resistivitas antara $4,51 \mathrm{~m}-52,85 \mathrm{~m}$ diduga terdapat batu lempung (clay).

Pada titik pengukuran Salas3 memiliki rentan kedalaman $85.84 \mathrm{~m}$ $5000 \mathrm{~m}$ dengan rentan nilai

resistivitas antara $6.56 \mathrm{~m}-51,27 \mathrm{~m}$ diduga terdapat batu lempung (clay). Titik pengukuran $1972 \mathrm{~m} 9 \mathrm{a}$ memiliki rentan kedalaman $71,17 \mathrm{~m}-5000 \mathrm{~m}$ dengan rentan nilai resistivitas $13,64 \mathrm{~m}-171,2 \mathrm{~m}$ diduga terdapat batu pasir berisi minyak (oil sands). Titik pengukuran SALM1M11 memiliki rentan kedalaman $39.52 \mathrm{~m} \mathrm{-}$ $5000 \mathrm{~m}$ dengan rentan nilai resistivitas 2,4 $\mathrm{m}-240,76 \mathrm{~m}$ diduga terdapat batu pasir berisi minyak (oil sands).

\subsection{Model Penampang 1D Lithology Batuan}

Pada Tabel 4. merupakan tabel nilai resistivitas batuan (Telford, dkk., 1990), nilai resistivitas $1-100 \mathrm{~m}$ adalah batu lempung (clay) dan nilai resistivitas 4 $800 \mathrm{~m}$ adalah batu pasir berisi minyak (oil sands).

Persebaran nilai resistivitas sebesar 2 $\mathrm{m}-74.99 \mathrm{~m}$ yang diindikasikan terdapat batu lempung (clay). Gambar 4. merupakan model lithology batuan, resistivitas pada model lithology ini ditandai dengan warna biru sampai dengan warna kuning. Untuk persebaran resistivitas tinggi ditandai dengan warna kuning tua sampai dengan merah dengan nilai resistivitas sebesar $250 \mathrm{~m}$ dan diindikasikan sebagai batu pasir berisi minyak (oil sands).

Pada Gambar 5. borehole lithology, yaitu lithology batuan yang berbentuk sumur dari delapan titik pengukuran.

\subsection{Model Penampang Resistivitas 1D dan 2D}

Model 1D data Bula merupakan pemodelan yang dilihat secara persebaran nilai resistivitas, persebaran nilai resistivitas untuk model $1 \mathrm{D}$ data Bula sebesar $240 \mathrm{~m}$. Gambar. 6 merupakan model penampang resistivitas $2 \mathrm{D}$ yang dihasilkan dari inversi 1D.

Model penampang 2D hasil inversi 2D ditunjukkan pada Gambar 7. model penampang 2D ini menunjukkan kesamaan nilai resistivitas dan lithology batuan pada penampang 1D, yaitu adanya indikasi batu lempung (clay) pada nilai resistivitas $12 \mathrm{~m}$ - $33 \mathrm{~m}$ dan nilai resistivitas $41 \mathrm{~m}$ -

$250 \mathrm{~m}$ yang diindikasikan sebagai batu pasir berisi minyak (oil sands).

\subsection{Formasi Hidrokarbon Data Bula}

Dari ke delapan titik pengukuran terdapat beberapa formasi batuan yang di duga sebagai formasi hidrokarbon yang terbentuk. Pada model penampang resistivitas 2D hasil korelasi inversi 1D dan model penampang 2D hasil inversi 2D terdapat batuan Qpf, yaitu formasi fufa.

Dengan batuan berwarna kelabu muda dan berlapis tipis. Komponen batuan ini terdiri dari kuarsa, rijang, batu pasir, batu lanau dan batu lempung. Gambar 8. merupakan model penampang resistivitas formasi hidrokarbon yang di interpretasikan berdasarkan formasi batuan, yang terkandung dalam data Bula sebagai indikasi pembentukan suatu formasi resistivitas batuan.

Lintasan dua terdiri dari titik pengukuran BL12, BL08, 1872M6, SALM5M, 1872M7A, SALAS3, 1872M9A, SALM1M dengan arah Barat Laut - Tenggara. Formasi batuan yang berpotensi sebagai pembentukan hidrokarbon di daerah Bula ini hanya terdapat dua indikasi, yaitu reservoar dan caprock.

Indikasi tersebut dilihat dari keadaan geologi yang mencakup formasi batuan 
berdasarkan nilai resistivitas yang dimodelkan oleh penampang resistivitas $2 \mathrm{D}$.

Kedalaman sampai dengan $1600 \mathrm{~m}-$ $2700 \mathrm{~m}$ di bawah permukaan dengan nilai resistivitas $12 \mathrm{~m}$ - $33 \mathrm{~m}$ diduga terdapat batu lempung (clays) yang diindikasikan sebagai caprock.

Kedalaman 2700 m sampai dengan $5000 \mathrm{~m}$ dibawah permukaan dengan nilai resistivitas $41 \mathrm{~m}-250 \mathrm{~m}$ diduga batu pasir berisi minyak (oil sands). Sandstone merupakan batuan sedimen yang memiliki porositas dan permeabilitas yang cukup tinggi sehingga mampu menampung fluida dan dapat meloloskan fluida. Karakteristik batuan sandstone tersebut dapat diindikasikan bahwa batuan ini dapat bertindak sebagai batuan reservoar.

Batuan sedimen yang terdapat di Bula pada penelitian kali ini di perkuat dengan penelitian yang berjudul Pola Struktur dan Geodinamika Cekungan Bula dengan metode gaya berat menunjukkan batuan sedimen pratersier berada pada kedalaman $1000 \mathrm{~m}$ sampai dengan $3000 \mathrm{~m}$ di bawah permukaan (Setyanta dan Setiadi, 2007).

Sifat permeabilitas yang tinggi pada batuan sandstone ini menjadikan reservoar sebagai batuan pembawa atau penyalur aliran minyak maupun gas bumi untuk bermigrasi ketempat berakumulasinya

minyak dan gas bumi tersebut terperangkap.

Untuk jebakan atau trap pada formasi hidrokarbon ini termasuk pada jebakan struktural, yaitu terdapat jebakan antiklin. Jebakan antiklin merupakan punggung lipatan yang kemiringan kedua sayapnya ke arah saling berlawanan dan saling menjauh dengan bentuk cembung ke atas. Jebakan ini terdapat pada titik pengukuran Salm5m1 sampai dengan $1872 \mathrm{~m} 7 \mathrm{a}$.

Untuk jebakan atau trap pada formasi hidrokarbon ini termasuk pada jebakan struktural, yaitu terdapat jebakan antiklin. Jebakan antiklin merupakan punggung lipatan yang kemiringan kedua sayapnya ke arah saling berlawanan dan saling menjauh dengan bentuk cembung ke atas. Jebakan ini terdapat pada titik pengukuran Salm5m1 sampai dengan 1872m7a.

Untuk jebakan atau trap pada formasi hidrokarbon ini termasuk pada jebakan struktural, yaitu terdapat jebakan antiklin. Jebakan antiklin merupakan punggung lipatan yang kemiringan kedua sayapnya ke arah saling berlawanan dan saling menjauh dengan bentuk cembung ke atas. Jebakan ini terdapat pada titik pengukuran Salm5m1 sampai dengan $1872 \mathrm{~m} 7 \mathrm{a}$

Titik pengukuran data Bula yang diukur pada metode Magnetotelurik ini terdapat pada sesar geologi $\mathbf{D} / \mathbf{E}$, tepatnya berada pada titik BL08 dan 1872M6 yang. Pada sesar D dan E memiliki litologi batuan seperti TRJk, KTn dan Tmps.

\section{KESIMPULAN DAN SARAN}

\subsection{Kesimpulan}

1. Formasi hidrokarbon yang terdapat pada data Bula ini merupakan formasi batuan Fufa yaitu Qpf. Dengan batuan berwarna kelabu muda dan berlapis tipis. Formasi Qpf terdiri dari batuan pasir, batuan lanau dan batuan lempung.

2. Penampang resistivitas 2-D memiliki kedalaman $1600 \mathrm{~m}$ - 2700 di bawah permukaan dengan nilai resistivitas 12 $\mathrm{m}$ - $33 \mathrm{~m}$ diduga terdapat batu lempung (clays). Kedalaman $2700 \mathrm{~m}-$ $5000 \mathrm{~m}$ di bawah permukaan dengan nilai resistivitas $41 \mathrm{~m}-250 \mathrm{~m}$ diduga batu pasir (sandstone).

3. Model penampang 2D hasil inversi 2D menunjukkan kesamaan nilai resistivitas dan lithology batuan pada korelasi inversi 1D.

4. Formasi hidrokarbon yang terdapat di daerah Bula berdasarkan model penampang resistivitas $2 \mathrm{D}$ adalah batu pasir (sandstone) di duga sebagai reservoar, batu lempung (clays) diduga 
sebagai caprock, jebakan atau trap pada sistem petroleum ini termasuk pada jebakan struktural.

\subsection{Saran}

Adapun saran yang dapat diberikan pada penelitian data Bula adalah untuk mengidentifikasi formasi hidrokarbon dapat didukung dengan data gaya berat. Dalam pengukuran data Magnetotelurik perlu diperhatikan standar operasional pengukuran agar data yang diproses mendapatkan hasil yang maksimal.

\section{UCAPAN TERIMA KASIH}

Penulis mengucapkan terima kasih kepada Noor Muhammad Indra Giri (Pusat Survei Geologi, Bandung) sebagai pembimbing lapangan, serta Syamsurijal Rasimeng S.Si., M.Si dan Rustadi, S.Si., M.T. yang telah membimbing dan memberikan dukungan terhadap penyelesaian penelitian ini.

\section{DAFTAR PUSTAKA}

Boggs, S.Jr., 2001, Principals of Sedimentology and Stratigraphy (ed): Upper Saddle River, NJ Prentice Hall, 726 p.

Grandis, H., Widarto, D.S., Utomo, E.P., Waluyo, W., dan Hehuwat, F., 2005, Magnetotelluric resistivity imaging over the Kawengan oil field and Banyuasin prospect, Northeast Java.

Koesoemadinata, 1980, Geologi Minyak dan Gas Bumi, Jilid 1 Edisi Kedua, ITB Bandung.

Magoon, L.B., dan Dow, W.G., 1994, The Petroleum System from Source to Trap. America Association of Petroleum Geologist and Society of
Economic Paleantologist and Mineralogist v.4, p. 1110.

Moehadi, M., 2011, Fundamental of Petroleum Geology and Exploration, 06 Cekungan Sedimetasi.

Setyanta, B., dan Setiadi, I., 2007. Anomali Gaya Berat dan Tataan Tektonis Sekitar Perairan laut Banda dan Pulau Seram, Jurnal Sumber Daya Geologi v. XVII, no.6, Pusat Survei Geologi, hal $408-419$.

Simpson, F., dan Bahr, K., 2005, Practical Magnetotelluric, Cambridge University Press.

Smirnov, M.Y., 2003, Magnetotelluric Data Processing with a Robust Statical Procedure havinga high breakdown point, Geophysics. J. Int.152, 1-7.

Vozoff, K., 1991, The Magnetotelluric Methode, Electromagnteic Methode in Applied Geophysics. Application SEG.

Xiao, W., 2004, Magnetotelluric Exploration in the Rocky Mountain Foothills, Alberta: University of Alberta.

Zillman, N.j., dan Paten, R.J., 1975, Geology and Petroleum Prospects of Seram Island, Eastern Indonesia, A.P.E.A.J., v.15, No.1, p. 73-80. 


\section{LAMPIRAN}

Tabel 1. Nilai resistivitas dan kedalaman BL12, BL08 dan 1872M6

\begin{tabular}{|c|c|c|c|c|c|}
\hline \multicolumn{2}{|c|}{ Titik Pengukuran BL12 } & \multicolumn{2}{|c|}{ Titik Pengukuran BL08 } & \multicolumn{2}{|c|}{$\begin{array}{c}\text { Titik Pengukuran } \\
1872 \mathrm{M} 6\end{array}$} \\
\hline $\begin{array}{l}\text { Kedalaman } \\
\text { (m) }\end{array}$ & $\begin{array}{c}\text { Resistivitas } \\
\text { (ohm } \\
\text { meter) }\end{array}$ & $\begin{array}{l}\text { Kedalaman } \\
\text { (m) }\end{array}$ & $\begin{array}{c}\text { Resistivitas } \\
\text { (ohm } \\
\text { meter) }\end{array}$ & $\begin{array}{l}\text { Kedalaman } \\
\text { (m) }\end{array}$ & $\begin{array}{c}\text { Resistivitas } \\
\text { (ohm } \\
\text { meter) }\end{array}$ \\
\hline 95.3 & 63.46 & 156.63 & 63.46 & 73.72 & 66.1 \\
\hline 170.3 & 23.11 & 207.9 & 13.97 & 157.65 & 9.73 \\
\hline 255.95 & 51.27 & 219.78 & 46.06 & 236.3 & 28.45 \\
\hline 554.08 & 7.92 & 241.63 & 7.57 & 480.36 & 8.3 \\
\hline 1373.13 & 116.5 & 250.6 & 11.57 & 1108 & 5.08 \\
\hline 1689.73 & 66.1 & 257.16 & 19.67 & 1515.27 & 12.4 \\
\hline 3342.82 & 22.2 & 279.23 & 3.59 & 3187.71 & 74.99 \\
\hline 5000 & 171.2 & 5000 & 8.57 & 5000 & 41.62 \\
\hline
\end{tabular}

Tabel 2. Nilai resistivitas dan kedalaman SALM5M1, 1872M7A dan SALAS3

\begin{tabular}{|c|c|c|c|c|c|}
\hline \multicolumn{2}{|c|}{$\begin{array}{c}\text { Titik Pengukuran } \\
\text { Salm5ml }\end{array}$} & \multicolumn{2}{|c|}{$\begin{array}{c}\text { Titik Pengukuran } \\
1872 M 7 \mathrm{a}\end{array}$} & \multicolumn{2}{|c|}{ Titik Pengukuran Salas3 } \\
\hline $\begin{array}{l}\text { Kedalaman } \\
\text { (m) }\end{array}$ & $\begin{array}{c}\text { Resistivitas } \\
\text { (ohm } \\
\text { meter) }\end{array}$ & $\begin{array}{c}\text { Kedalaman } \\
\text { (m) }\end{array}$ & $\begin{array}{c}\text { Resistivitas } \\
\text { (ohm } \\
\text { meter) }\end{array}$ & $\begin{array}{l}\text { Kedalaman } \\
\text { (m) }\end{array}$ & $\begin{array}{c}\text { Resistivitas } \\
\text { (ohm } \\
\text { meter) }\end{array}$ \\
\hline$\$ 1.75$ & 23.11 & 115.58 & 22.2 & 85.84 & 51.27 \\
\hline 113.47 & 10.82 & 164.62 & 11.66 & 159.28 & 11.88 \\
\hline 193.69 & 28.84 & 293.7 & 19.69 & 212.95 & 21.85 \\
\hline 336.59 & 4.54 & 569.34 & 7.45 & 544.54 & 8.97 \\
\hline 472.26 & 10.15 & 931.59 & 4.51 & 948.9 & 6.56 \\
\hline 866.65 & 2.75 & 1204.14 & 9.59 & 1225.49 & 22.07 \\
\hline 1740.84 & 7.78 & 2386,12 & 52.85 & 2100.01 & 40,78 \\
\hline 5000 & 19.02 & 5000 & 28.26 & 5000 & 29.21 \\
\hline
\end{tabular}

Tabel 3. Nilai resistivitas dan kedalaman 1872M9A dan SALM1M11

\begin{tabular}{|c|c|c|c|}
\hline \multicolumn{2}{|c|}{$\begin{array}{c}\text { Titik Pengukuran } \\
\text { 1872m9a }\end{array}$} & \multicolumn{2}{c|}{$\begin{array}{c}\text { Titik Pengukuran } \\
\text { SalMiMl1 }\end{array}$} \\
\hline $\begin{array}{c}\text { Kedalaman } \\
\text { (m) }\end{array}$ & $\begin{array}{c}\text { Resistivitas } \\
\text { (ohm } \\
\text { meter) }\end{array}$ & $\begin{array}{c}\text { Kedalaman } \\
\text { (m) }\end{array}$ & $\begin{array}{c}\text { Resistivitas } \\
\text { (ohm } \\
\text { meter) }\end{array}$ \\
\hline 71.17 & 171.2 & 39.52 & 7.92 \\
\hline 193.78 & 13.64 & 65.63 & 2.4 \\
\hline 337.95 & 32.75 & 126.44 & 14.46 \\
\hline 541.76 & 17.84 & 260.98 & 2.8 \\
\hline 2022.88 & 29.13 & 678.56 & 5.4 \\
\hline 2592.08 & 53.8 & 872.14 & 11.17 \\
\hline 4939.1 & 106.89 & 3508.97 & 240.76 \\
\hline 5000 & 63.62 & 5000 & 19.73 \\
\hline
\end{tabular}

Tabel 4. Nilai resistivitas batuan

\begin{tabular}{|c|c|}
\hline Tipe Batuan & Nilai Resistivitas $(\mathbf{\Omega m})$ \\
\hline Andesit & $4.5 \times 10^{4}-1.7 \times 10^{2}$ \\
\hline Lavas & $10^{2}-5 \times 10^{4}$ \\
\hline Gabbro & $10^{3} \times 10^{6}$ \\
\hline Basalt & $10-1.3 \times 10^{7}$ \\
\hline Tuffs & $2 \times 10^{3}-10^{5}$ \\
\hline Shales & $20-2 \times 10^{5}$ \\
\hline Conglomerat es & $2 \times 10^{3}-10^{4}$ \\
\hline Sandstones & $1-6.4 \times 10^{5}$ \\
\hline Limestones & $50-10^{7}$ \\
\hline Marls & $3-70$ \\
\hline Clays & $1-100$ \\
\hline Oil Sands & $4-800$ \\
\hline Graphite schist & $10-100$ \\
\hline
\end{tabular}




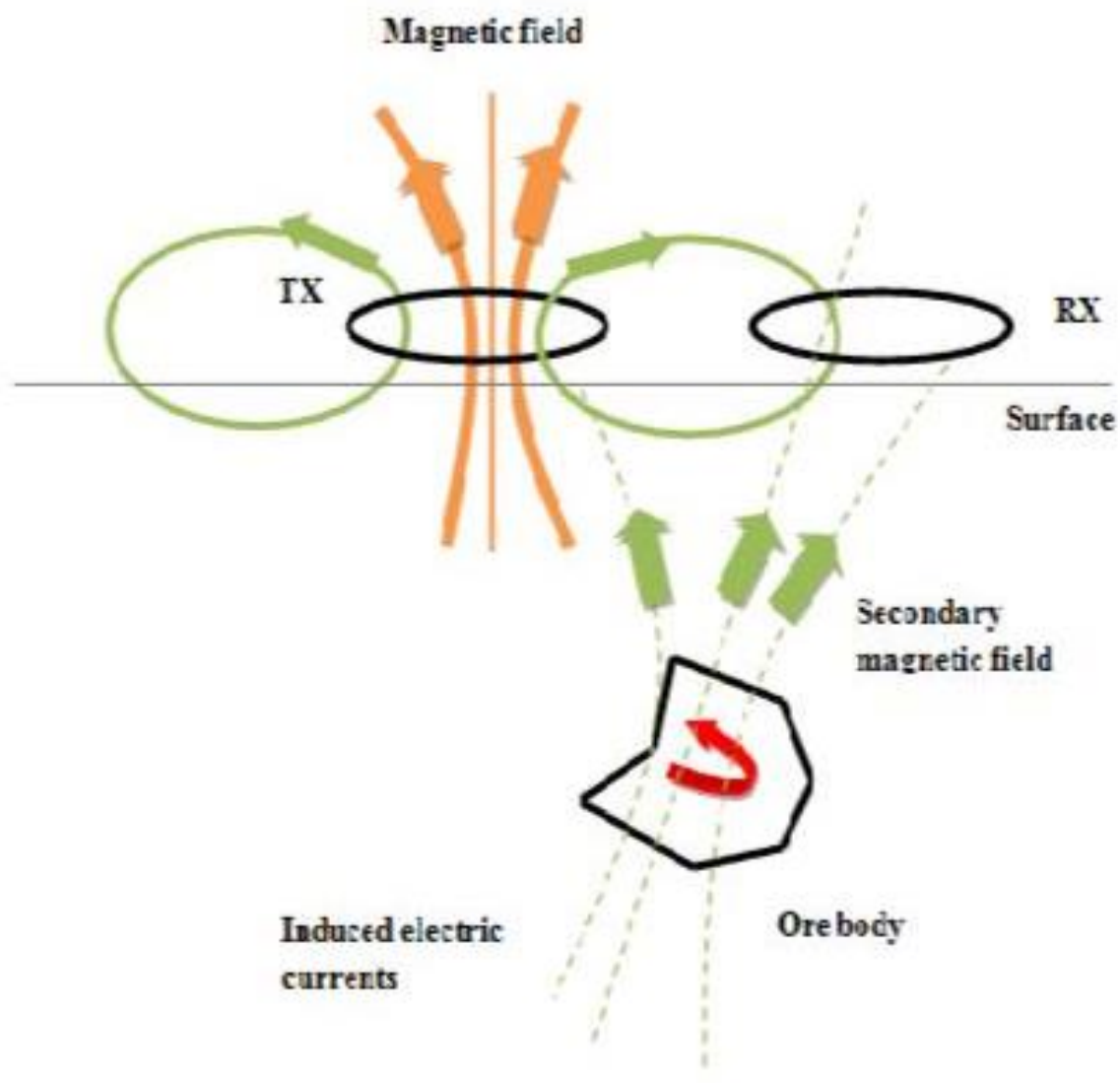

Gambar 1. Fenomena penjalaran gelombang (Unsworth, 2006)
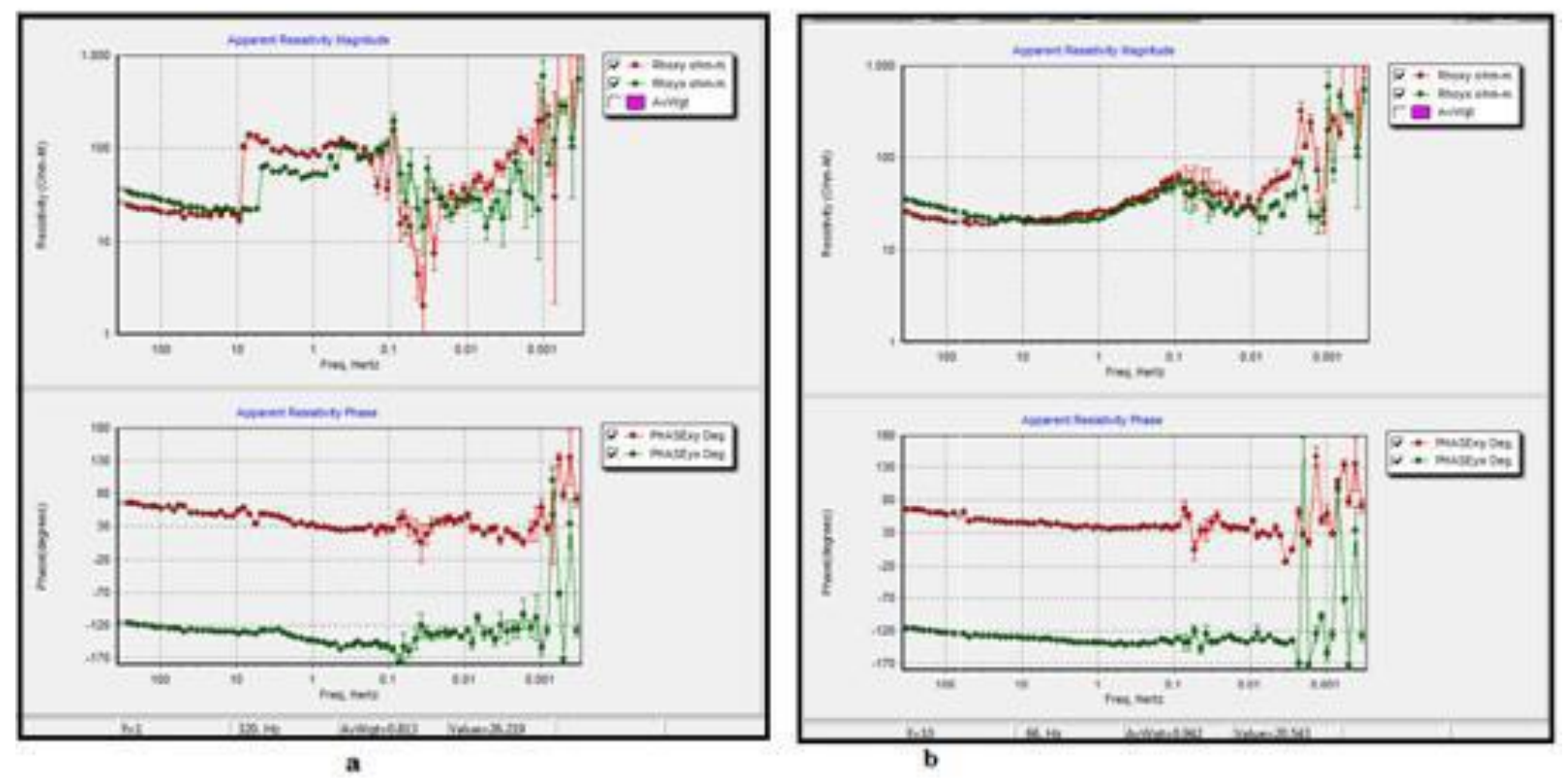

Gambar 2. Sebelum seleksi XPR (a), Setelah seleksi XPR(b) 


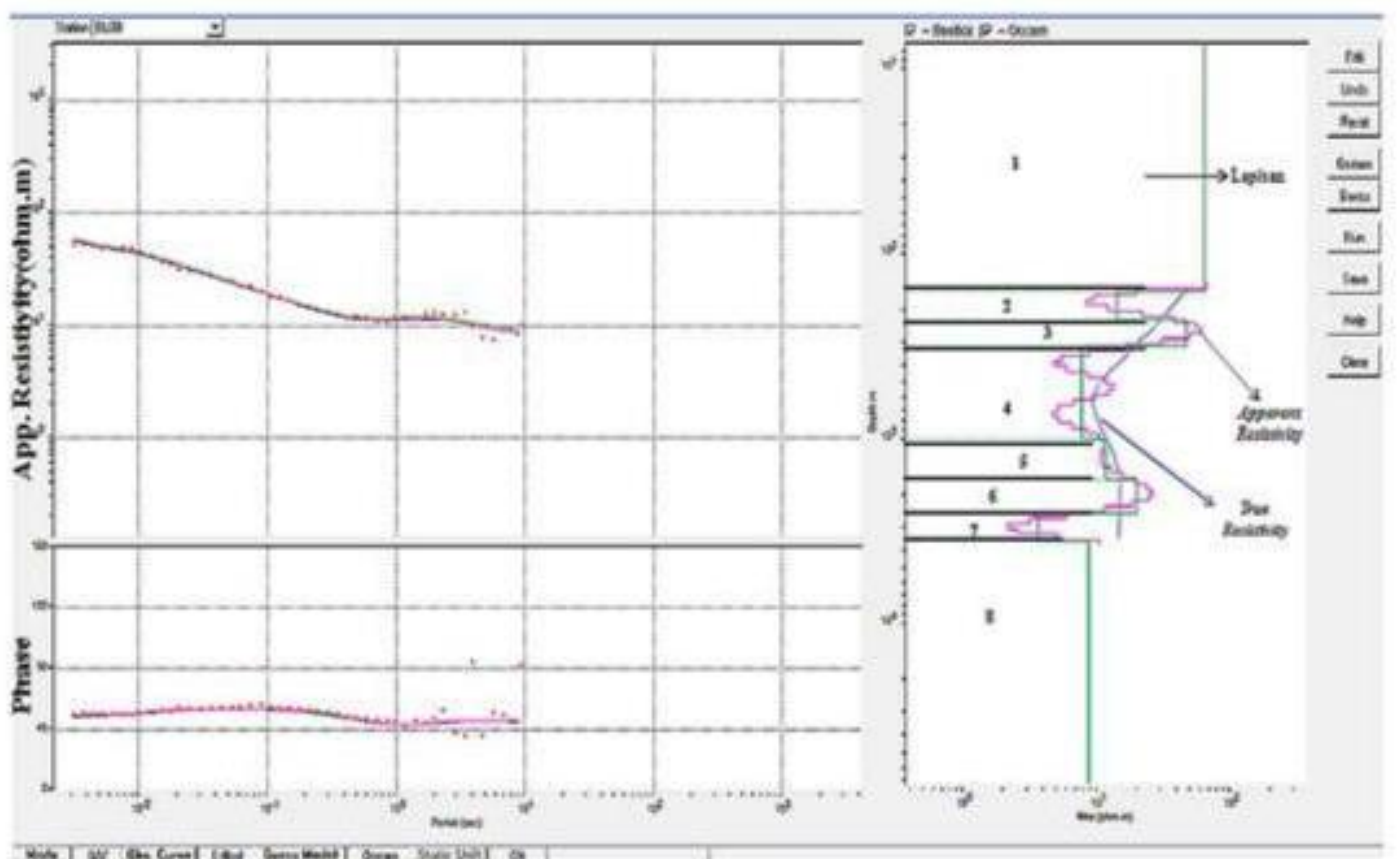

Gambar 3. Model sounding 1-D

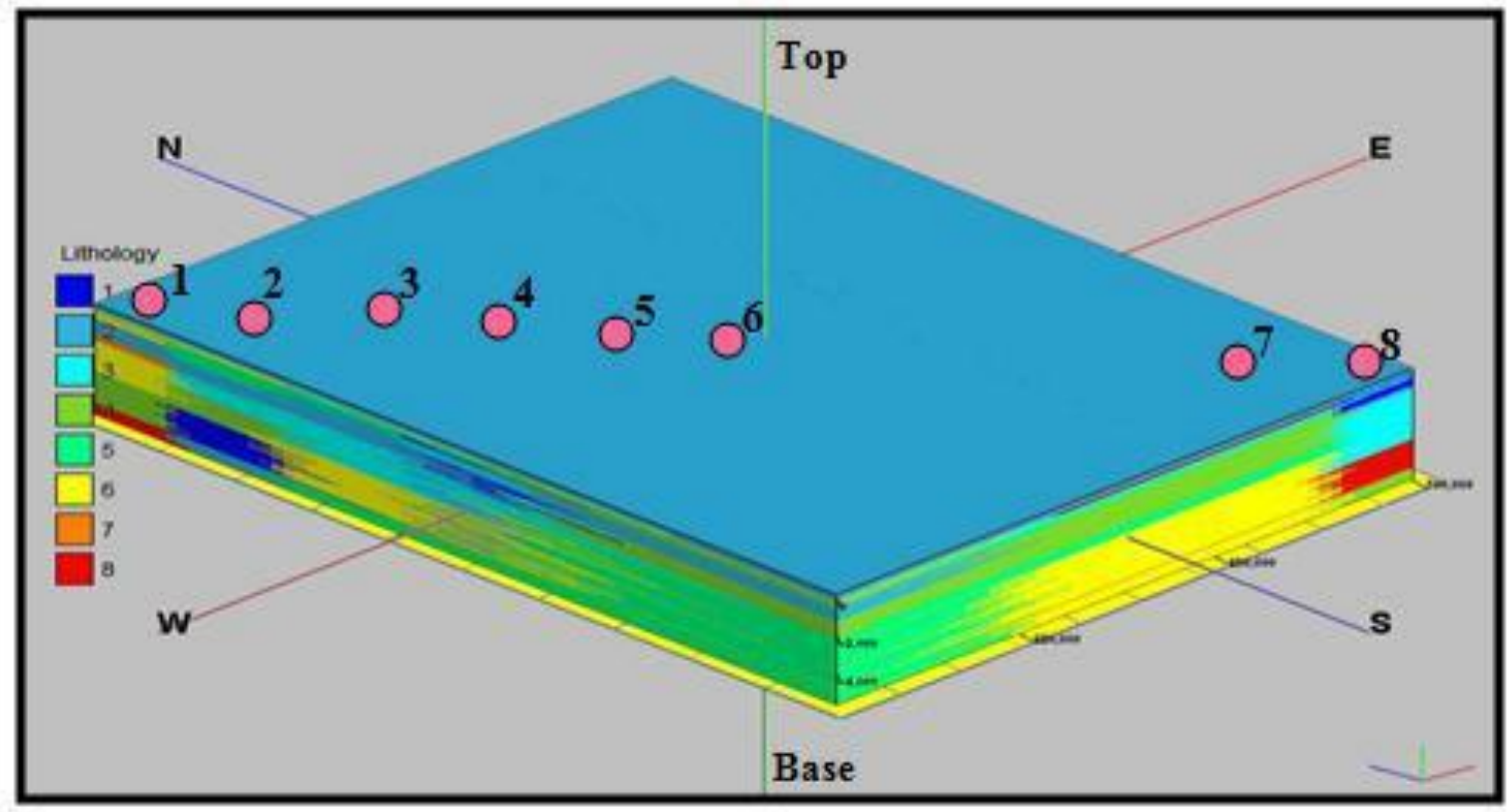

Gambar 4. Model lithology batuan 


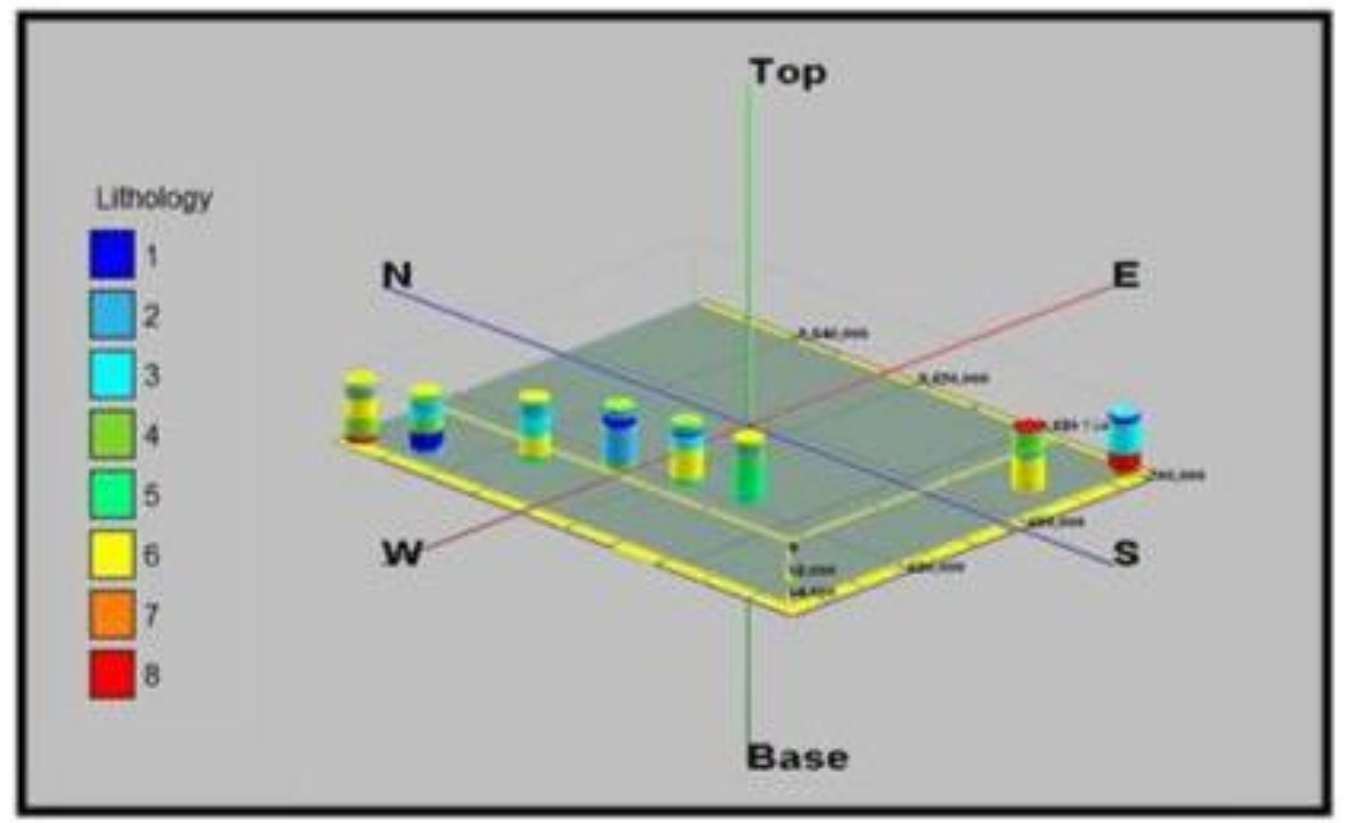

Gambar 5. Borehole lithology batuan

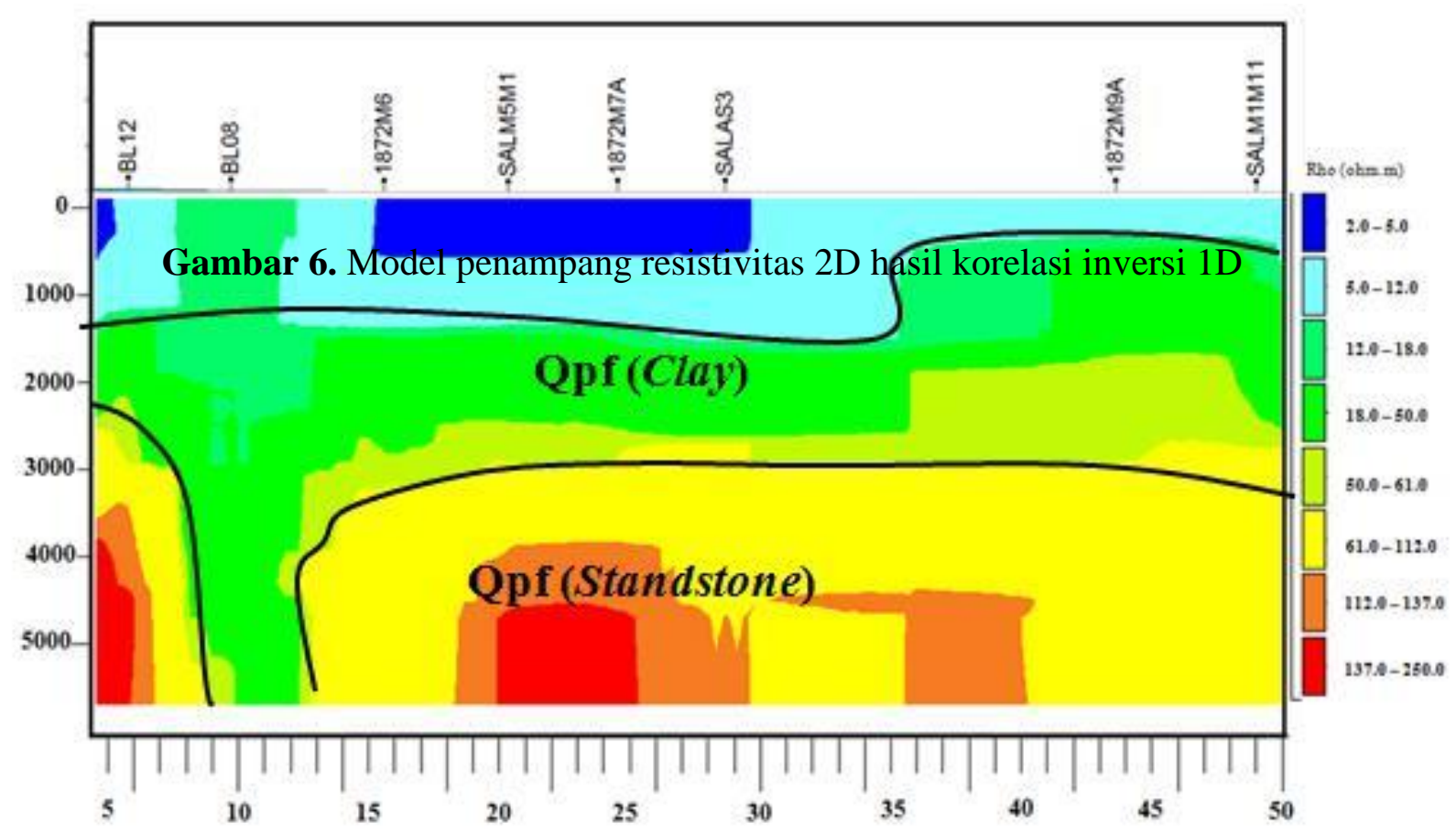

Gambar 6. Model penampang lithology 1D 


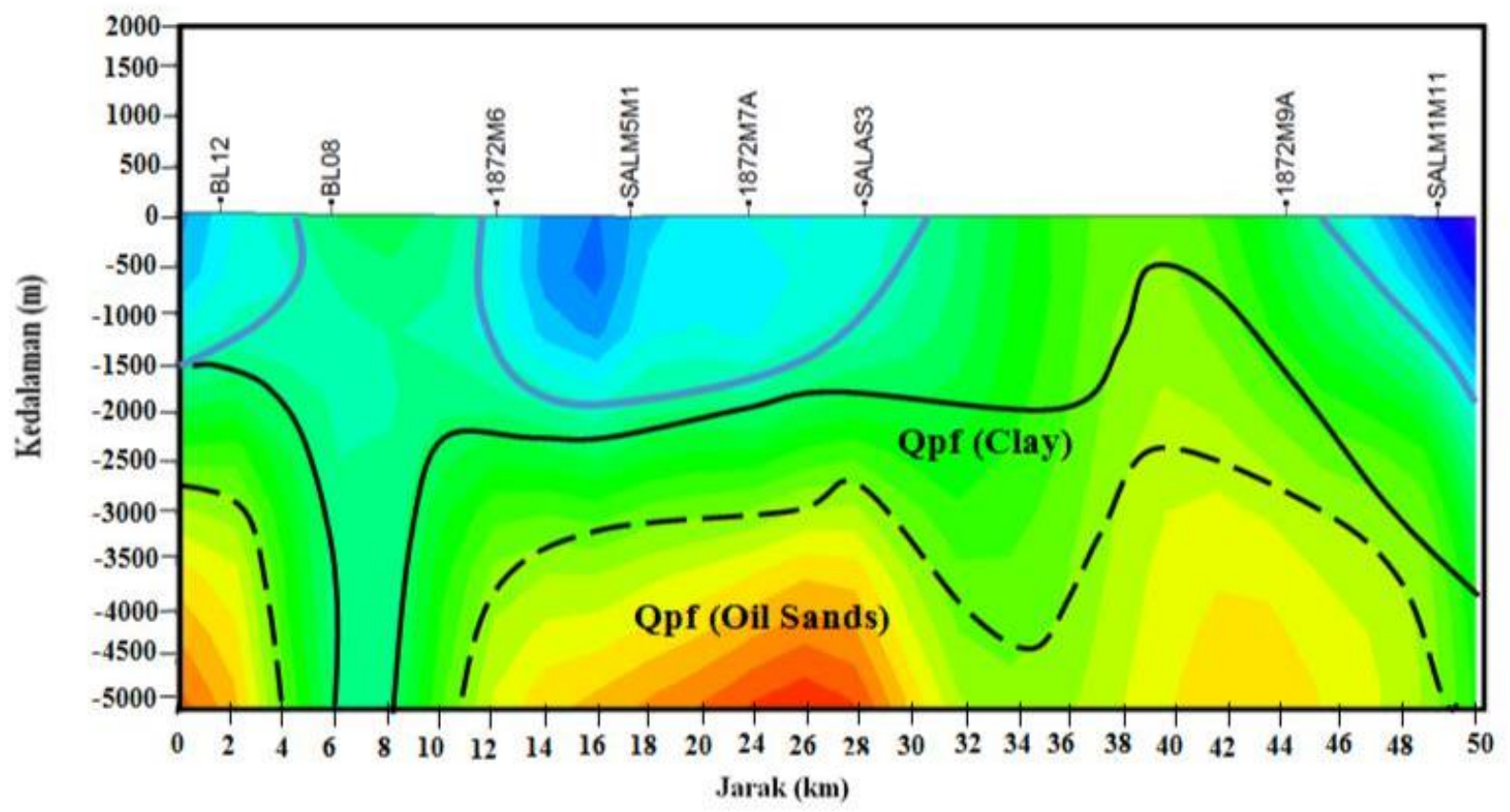

Gambar 7. Model penampang 2D hasil inversi 2D

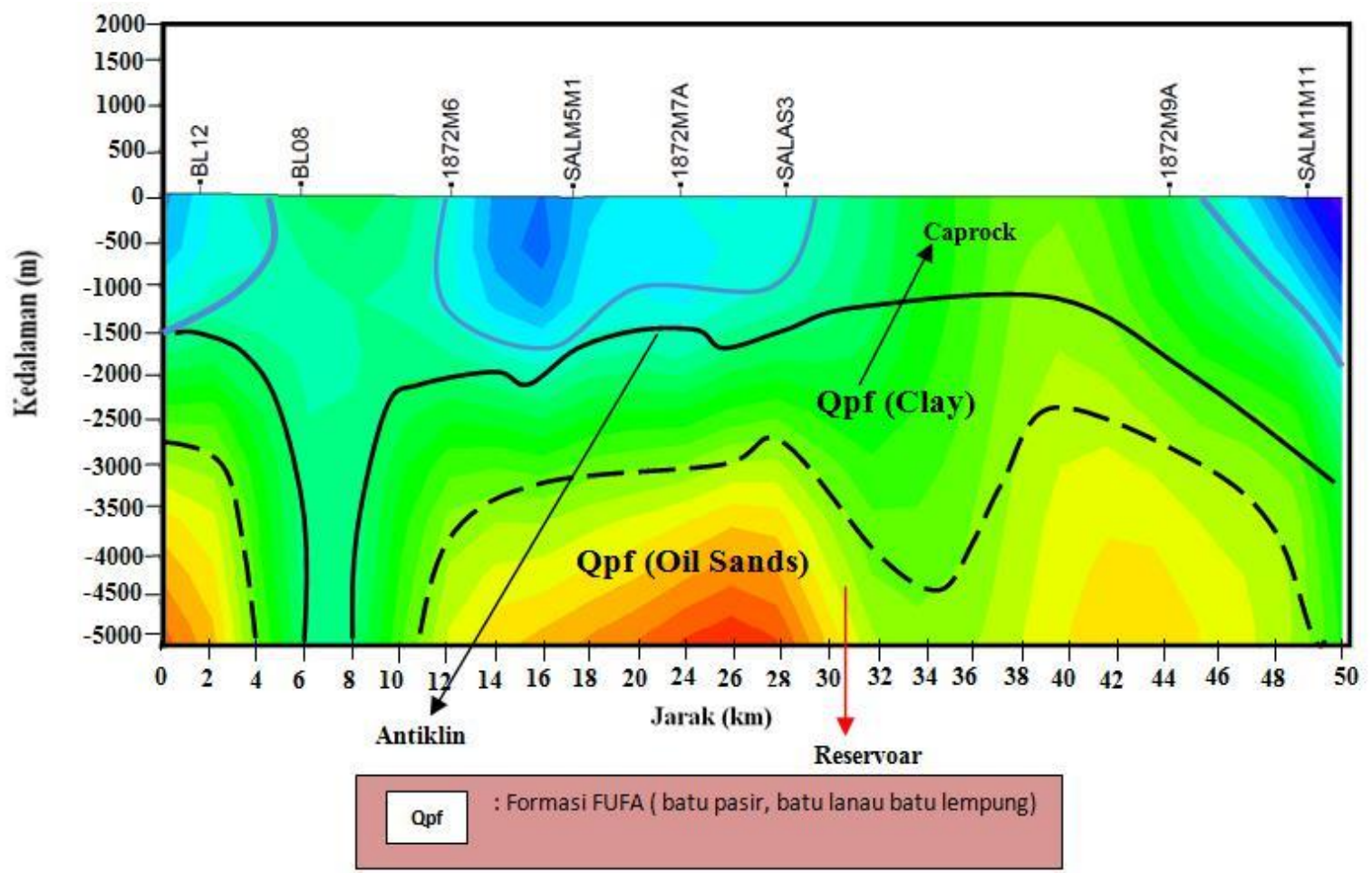

Gambar 8. Model penampang resistivitas 2D formasi hidrokarbon 